\title{
Del sentido histórico a la agenda ampliada: la experiencia de la Mesa de Trabajo por los Derechos Humanos de Córdoba, Argentina
}

Ana Carol Solis ${ }^{1}$

Resumen: El artículo analiza la experiencia de la Mesa de Trabajo por los Derechos Humanos de Córdoba como referente paradigmático de articulación entre viejos y nuevos modos del compromiso político en el momento de su conformación y consolidación. En particular, reflexiona sobre las complejidades de la acción política y la cuestión de los derechos humanos en un régimen de historicidad diferente al relacionarlas con las derivas del tratamiento político e institucional de las demandas que la Mesa expresaba.

Palabras claves: Mesa de Trabajo; Córdoba; experiencia

\section{From Historical Sense to the Expanded Agenda: The Experience of Mesa de Trabajo por los Derechos Humanos in Córdoba, Argentina}

\begin{abstract}
This paper analyzes the Mesa de Trabajo por los Derechos Humanos in Córdoba, Argentina, as a paradigm case between old and new ways of political articulation, focusing on the moment of its formation and consolidation. It reflects on the complexities of political action and human rights' issues in a different historicity regime by relating them to the drifts of political and institutional treatment of the demands of the Mesa.
\end{abstract}

Keywords: Human Rights' Workshop; Córdoba; experience

Artigo recebido em: 14/04/2020

Artigo aprovado para publicação em: 06/07/2020

\footnotetext{
${ }^{1}$ Doctora en Estudios Sociales de América Latina, Magister en Partidos Políticos, Licenciada y Profesora en Historia, por la Universidad Nacional de Córdoba (UNC), Argentina. Investigadora del Centro de Investigaciones María Saleme de Burnichón (CIFFyH.), Facultad de Filosofía y Humanidades y docente de la UNC. Dirige el proyecto "Militancias, dictaduras y derechos humanos en la historia reciente de Córdoba. II Etapa”, con subsidio de Secretaría de Ciencia y Tecnología de la UNC. Dirección, Punta del Este 4456, Parque Latino, Ciudad de Córdoba, Argentina. E-mail: acarolsolis@yahoo.com.ar.
} 


\section{Introducción}

En Argentina, el origen histórico y la trayectoria posterior de ciertos actores colectivos asociados al entramado de los derechos humanos -en alusión a las respuestas sociales que produjo el terror de Estado- ha sido objeto de investigación de diversas áreas de conocimiento, abordándose principalmente la etapa de su lucha antidictatorial y su acción en la posdictadura. Con posterioridad, la cuestión de los derechos humanos, entendida como la problematización social de ese tema o demanda en la que los mismos quedaron inscriptos, tuvo oscilaciones en su visibilidad; ligadas éstas a las políticas estatales, a la propia historia de sus sostenedores - el Movimiento por los Derechos Humanos (en adelante MDH) - y a modificaciones más profundas que atañen a las formas, espacios y contenidos del activismo y, en general, de las culturas políticas. Dentro de este marco general, y en sintonía con quienes abordan la especificidad de los espacios provinciales y regionales en la configuración de los derechos humanos, se propone analizar la experiencia de la Mesa de Trabajo por los Derechos Humanos de Córdoba (en adelante MTDHC) como referente paradigmático de articulación entre viejos y nuevos modos del compromiso político ${ }^{2}$.

En ella concurren diferentes generaciones de activistas, desde los organismos históricos - con un marcado protagonismo de Hijos e Hijas por la Identidad y la Justicia contra el Olvido y el Silencio (H.I.J.O.S.) - a novedosas organizaciones sociales, políticas y culturales, sin excluir a otros clásicos, como ciertos espacios sindicales, pero con un sesgo más propio de las culturas políticas de las y los jóvenes de un tiempo finisecular. La construcción de agenda, los repertorios y ocasiones de la acción, las redes y las

\footnotetext{
${ }^{2}$ El artículo es una versión corregida de la ponencia homónima en las Jornadas Interescuelas / Departamentos de Historia del año 2011, Catamarca, Argentina. Agradezco los comentarios allí recibidos de los integrantes de la mesa. Igualmente agradezco las observaciones y sugerencias de Emiliano Fessia a esa misma versión. También los aportes de los/as integrantes del equipo de investigación que dirijo en el Área Historia del CIFFyH de la Facultad de Filosofía y Humanidades de la Universidad Nacional de Córdoba, Argentina.
} 
trayectorias consideradas permiten establecer rasgos de un estilo de militancia renovada que reactualizó de manera novedosa las herencias de aquellas modalidades previas con las que está en diálogo. Entonces, las derivas del sentido público en la lucha por los derechos humanos dicen también sobre los modos en que varían las formas de la politicidad juvenil, ofreciendo una clave de lectura singular para indagar los procesos de movilización y politización contemporáneos. El trabajo abreva para ello en los aportes de la nueva historia política, los estudios de acción colectiva y del compromiso militante. Se detiene, muy especialmente, en los usos del pasado en la construcción política e identitaria que realizan los actores movilizados, urdiendo tramas temporales complejas que ayudan a legitimar modos de estar en el mundo.

Oberti y Pittaluga (2006) refieren en la introducción de su obra al deber de memoria y a la importancia de la trasmisión entre generaciones, importancia ésta que se traduce en un conjunto de interrogantes y desafíos específicos que tal empresa colectiva alberga; máxime cuando ella ha sido profundamente interrumpida (incluso negada, imposibilitada y hasta hostigada podríamos decir) por la experiencia límite del terror de Estado. Reconociendo estos desafíos, ¿cómo opera la trasmisión en las generaciones del $\mathrm{MDH}$ ? ¿Y cómo lo hace hacia afuera de estas organizaciones? ¿De qué manera el pasado actuante (y actuado) es parte de las construcciones políticas del presente? ¿Qué pasados son seleccionados en las operaciones de legitimación de los movimientos sociales y en general de los actores cuando se movilizan? ¿Cómo se ligan estas cuestiones con el régimen de historicidad desde los actores que analizamos? Según Hartog (2007), vivimos un nuevo régimen de historicidad caracterizado por el ascenso veloz de la categoría de presente "que ha llevado a imponer la evidencia de un presente omnipresente"; un régimen que él denomina "presentismo" (HARTOG, 2007, p. 28). De allí que propone el concepto de régimen de historicidad para asir los diversos modos de relacionarse con el tiempo, modos que implican también momentos de crisis, como el que atisba al considerar que el régimen de historicidad moderno ha sido puesto en duda, porque la distancia entre el campo de la experiencia y el horizonte de la espera (o expectativas según proponen 
otras traducciones) implica una tensión y alejamiento constante. Eso hace de la experiencia contemporánea "un presente perpetuo, huidizo y casi inmóvil, que intenta a pesar de todo producir por sí mismo su propio tiempo histórico. Todo sucede como si ya no hubiera más que presente [...]" (HARTOG, 2007, p. 40). Sin embargo, en sociedades posdictatoriales, marcadas por experiencias límites de represiones inusitadas como fueron las últimas dictaduras de seguridad nacional en el cono sur de América Latina, ¿ese presentismo cómo se articula con los procesos de memoria, verdad y justicia en sociedades con historias fracturadas que alternaron fases de juzgamiento y reparación con otras de desprocesamiento e impunidad? Y más en concreto, en las construcciones políticas y militantes de las luchas por derechos humanos en Argentina, ¿de qué modos habitan las temporalidades y cómo lo hacen en esas legitimaciones políticas y actuaciones públicas? El artículo procura recorrer - con diferentes densidades- estos interrogantes desde la reconstrucción de una experiencia de organización y acción política novedosa en la historia del MDH como fue la Mesa de Trabajo.

La MTDHC permanece desde fines de los años noventa y se ha constituido en un espacio singular que, signado en sus inicios por algunos rasgos e improntas propias de cierta politicidad juvenil de los años noventa, ha podido entramar convenientemente a diferentes generaciones de militantes y ha logrado instalarse como una instancia de coordinación interorganizacional que, en las últimas décadas, tuvo y tiene una fuerte presencia en la agenda del legado pendiente de la dictadura, pero también en relación a otros conflictos asociados al paradigma de los derechos humanos de situaciones vividas en Córdoba, el país y la región. En la actualidad, la Mesa sigue siendo el organizador principal de la conmemoración del 24 de marzo, aniversario del Golpe de Estado producido en 1976 que inauguró la última dictadura en Argentina, articulando con diferentes organizaciones, colectivos e instituciones las actividades de la serie conmemorativa. A su vez, participa de acciones de coordinación permanentes sobre otras temáticas que sus integrantes consideran relevantes debatir, denunciar o apoyar y 
promueve anualmente diferentes acciones, como los Encuentros provinciales de Derechos Humanos ${ }^{3}$.

Particularmente, este artículo aborda su momento formativo y de consolidación, el que ubicamos por su actuación a fines del siglo pasado y en los primeros años del siglo vigente, instancia crucial en la que desde espacios diversos -a veces invisibilizados- se construyeron resistencias al modelo neoliberal y prácticas políticas novedosas. Estas resistencias ofrecen claves interesantes para pensar (por fuera de este escrito) los desafíos cambiantes e incluso otros más actuales del MDH como trabajar desde el Estado, cuando sus reclamos se convirtieron en parte de las políticas públicas impulsadas por los gobiernos nacional, provincial y municipal a partir del dos mil y con variaciones, según los signos políticos de cada administración. Lo que se presenta a continuación es, entonces, una caracterización de este actor en un determinado momento histórico, marcado por su formación y consolidación como nuevo agente del entramado en las luchas por derechos humanos ${ }^{4}$, y una primera aproximación a los interrogantes sobre las temporalidades entre generaciones y en la acción colectiva, siendo necesario continuar en futuras investigaciones. En este artículo se sostiene que el surgimiento de la Mesa requiere ser inscripto en un proceso más amplio de vuelta a escena de la cuestión de los derechos humanos tanto en su sentido histórico como en las resignificaciones que se

\footnotetext{
${ }^{3}$ En su agenda más reciente, por ejemplo, la Mesa lleva un registro de las muertes ocurridas en situaciones en las que participaron agentes de seguridad, especialmente sobre jóvenes víctimas. Esta cuestión que desde mediados de los años noventa se configuró como "Gatillo fácil" ha tematizado las formas vigentes de la violencia institucional y el uso de la fuerza letal contra los/as jóvenes, principalmente de barriadas populares. También se ha posicionado repudiando la estigmatización de las militancias durante los años de la gestión de Mauricio Macri como presidente, denunciando la persecución y los allanamientos a organizaciones sociales y políticas principalmente juveniles. Incluso, en la actualidad participa de la judicialización del reclamo por la posible comisión de delitos de lesa humanidad en el golpe de Estado producido en Bolivia en 2019, junto a otras organizaciones e institucionales locales, mediante su integración al Comité de Solidaridad que se conformó en la provincia.

${ }^{4}$ Luchas por derechos humanos es la categoría que propone Luciano Alonso dada la variabilidad de las experiencias que se nombran y se autoidentifican en la expresión de derechos humanos (ALONSO, 2018; 2019). En este artículo, entiendo que esa categoría es también válida para nominar el espacio de las luchas a que se integró la Mesa, pero en cuanto a proceso de construcción pública de problemas que requieren de una solución social prefiero denominarlo cuestión de los derechos humanos, como explicitaré más adelante.
} 
fueron operando en paralelo a la agudización de la situación socio - económica y la pérdida o falta de efectivización de derechos antes garantizados. Con sentido histórico refiero al mantenimiento de las demandas clásicas del MDH en relación al problema de la verdad, la justicia y luego la memoria sobre los crímenes cometidos en dictadura. Las nuevas resignificaciones hacen a las actualizaciones (por ejemplo los sentidos asociados a la militancia de lo/as represaliado/as) y también a las aperturas temáticas en relación a nuevos conflictos que los posicionaban. Con agenda ampliada refiero, entonces, a la incorporación de nuevas injusticias o demandas por derechos que han sido inscriptas en el relato y marco cognitivo de los derechos humanos e incorporadas a la acción del MDH. Ambas expresiones han sido usadas por mí en el análisis de la cuestión de los derechos humanos en los noventa en mi tesis de maestría, trabajo previo de investigación del que este artículo es una profundización sobre un actor emergente en aquel período que no ha sido aún objeto de reflexiones más sistemáticas ${ }^{5}$.

En otras palabras, sostenemos que resulta de algún modo insuficiente remitir a la propia historia del MDH para dar cuenta de la conformación de la MTDHC y de lo que serán sus rasgos identitarios, modos de inscripción pública y definiciones políticas. Es en el interjuego entre los actores que la conforman, las ocasiones y sus definiciones que podremos acercarnos a la singularidad de una experiencia exitosa que ha logrado constituirse en una instancia de coordinación permanente con incidencia en la conformación de una agenda ampliada de los Derechos Humanos en Córdoba. Con respecto a las fuentes documentales utilizadas, el acercamiento a la temática se realizó mediante la consulta a la Base de datos de acción Colectiva en Córdoba, 1989-20036 ${ }^{6}$ Este

\footnotetext{
${ }^{5}$ Ver SOLIS, 2011.

${ }^{6}$ La confección de dicha base es el resultado principal de los equipos de investigación dirigidos por la Dra. Mónica Gordillo en el Área de Historia del CIFFyH UNC, de los que formé parte desde el año 2002 al 2015. Tomando como unidad de registro las acciones colectivas de protesta a partir de un relevamiento exhaustivo de la prensa gráfica local, la base arroja datos sobre la frecuencia, las ocasiones, los formatos de la protesta, los organizadores y adherentes y las demandas, tipificando además 17 tipos de protesta. Dentro de ese equipo me especialicé en las demandas por derecho humanos y justicia y parte de mi trabajo en él fue objetivado como tesis de Maestría en Partidos Políticos del Centro de Estudios Avanzados de la UNC (SOLIS, 2011).
} 
relevamiento y entrecruzamiento de datos realizado a partir de su procesamiento con el programa $\operatorname{SSPS}^{7}$ fue complementado con el análisis de las notas periodísticas, materiales producidos por las organizaciones bajo estudio, principalmente de los volantes y panfletos de distribución pública, cartas entre organizaciones y de material interno de las mismas, pertenecientes a mi colección personal y otras cedidas gentilmente por colegas ${ }^{8}$.

\section{La cuestión de los derechos humanos en perspectiva local}

Una muy breve historización de la cuestión de los derechos humanos en la provincia de Córdoba, Argentina, indica que aquí hubo antecedentes concretos a la conformación del MDH en las luchas defensistas protagonizadas -por lo menos desde la segunda mitad del siglo $\mathrm{XX}$ - por diferentes colectivos políticos y sociales, con fuerte impronta de los familiares, las militancias y los abogados comprometidos, en particular desde el aumento de la radicalización política y social ocurrida en las décadas de 1960 y 1970. Las comisiones de solidaridad con los presos políticos, gremiales y estudiantiles configuran la expresión más corriente de esa forma de reclamo y acción denunciativa. Una vez retornado al poder el gobierno peronista en 1973, a nivel nacional y provincial, desde 1974 la represión y la violencia legal e ilegal, estatal y paraestatal se incrementó por un golpe policial que destituyó a las autoridades provinciales democráticamente electas. Este acontecimiento marcó el giro a la derecha del peronismo gobernante y la progresiva militarización de la escena política, con un gobierno intervenido federalmente hasta el golpe de Estado de 1976. Esta nueva coyuntura remotorizó organizaciones y modos de actuar para denunciar la escalada represiva e incluso la indeterminación de las autorías de tales violaciones que comenzaron a incluir, además de las prisiones,

\footnotetext{
${ }^{7}$ Es un software utilizado para realizar la captura y análisis de datos que permite crear tablas y gráficas con datos complejos, con él se trabajaron los resultados de la base de datos. Permitió mapear años de protesta, ciclos, formatos de protesta más usados, entre otros resultados.

${ }^{8}$ Agradezco los materiales compartidos por Ana Natalucci y Leandro Inchauspe.
} 
allanamientos y torturas a las desapariciones transitorias o permanentes desde el último tercio del año 1975. Cuando se produjo el golpe de Estado el 24 de marzo de 1976, una parte sustancial de las antiguas formas de llevar adelante la lucha defensista había sido desarticulada por la represión o se había mostrado insuficiente, mientras se habían comenzado a nuclear grupos nuevos en coincidencia con el avance represivo. La ferocidad de la represión local bajo las órdenes del entonces general Luciano Benjamín Menéndez a cargo del Comando del III Cuerpo de Ejército ralentizó la acción defensista en los primeros tiempos posgolpe, siendo los propios familiares de los represaliados y hasta los abogados igualmente convertidos en blancos represivos. La imposibilidad de contar con aliados locales hizo que tempranamente los familiares y allegados de las víctimas, así como pequeñas redes solidarias se contactaran con las organizaciones que se iban conformando en otras provincias, principalmente con Buenos Aires. Fue en ese marco que se organizaron núcleos novedosos con el acompañamiento de otras organizaciones ya existentes, como la Liga Argentina por los Derechos del Hombre (LADH), el Movimiento Ecuménico por los Derechos Humanos (MEDH) y la Asamblea Permanente por los Derechos Humanos (APDH). En ese magma se formó lo que se conoció luego como Familiares de Desaparecidos y Detenidos por Razones Políticas en Córdoba y también se establecieron vínculos y pertenencias a la organización de Abuelas de Plaza de Mayo, aunque su formalización como filial local se conoció a la salida de la dictadura. Desde la etapa posterior a la derrota en la guerra de Malvinas procede la organización local del Servicio de Paz y Justicia (SERPAJ) en esta ciudad también. De esto modo, en la inmediata posdictadura el arco de las organizaciones viejas y nuevas que tuvieron presencia en la ciudad de Córdoba incluyó a LADH, APDH, FDDRP, APM, MEDH y SERPAJ. Luego se conformaron nucleamientos de ex presos ya en democracia. El MDH sufrió en los ochenta y primeros noventa los avatares del propio tratamiento de la cuestión. A mediados de los noventa se conformó la agrupación Hijos e Hijas por la Identidad y la Justicia contra el Olvido y el Silencio (H.I.J.O.S.), que redinamizó el 
espacio de las luchas y logró agenciar a nuevas generaciones en el reclamo de esta causa ${ }^{9}$. Como argumenta María Paula Puttini (2020), conformada en 1995 y siendo parte de la Red Nacional desde sus comienzos, H.I.J.O.S. Córdoba resignificó las viejas demandas de memoria, verdad y justicia e incorporó otras nuevas, como por ejemplo, los casos de gatillo fácil. A su vez, articuló la participación política de los jóvenes por fuera de los partidos y la militancia universitaria (que habían primado en los años ochenta democráticos) en un contexto de crisis y reformulación de la participación política y juvenil. Igualmente, la historiadora señala que "desde su aparición en el espacio público la agrupación H.I.J.O.S. en Córdoba se mostró como innovadora y regeneradora de demandas que habían quedado desplazadas de la agenda pública en los noventa proponiendo nuevas formas de protesta" (PUTTINI, 2020, p. 144).

\section{Los inicios: "como una necesidad frente a la impunidad"}

En una perspectiva temporal más amplia, anclada en la historia local de los organismos de derechos humanos que integran el MDH y el proceso más general de los itinerarios públicos de los derechos humanos como cuestión de debate ${ }^{10}$, la conformación de la MTDHC es la expresión de una tendencia a la creación de espacios de coordinación permanentes que se había comenzado a insinuar en la provincia ya hacia 1994, con iniciativas de actores diversos que buscaban entramar sus conflictos y luchas hacia una pretensión de generalización de los reclamos que, hasta entonces, había sido por demás limitada $^{11}$. En el devenir de la cuestión de los derechos humanos, la reactualización de

\footnotetext{
${ }^{9}$ Para profundizar en las claves locales, remitimos a SOLIS, 2014 y 2019. Con referencia a los años noventa, SOLIS, 2012 y para la conformación de H.I.J.O.S. ver PUTTINI, 2020.

${ }^{10}$ Entiendo la cuestión de los derechos humanos desde una perspectiva constructivista, es decir como proceso de problematización de una cuestión socialmente relevante (SOLIS, 2012).

${ }^{11}$ Una característica de la conflictividad social de la primera mitad de la década de los años noventa en Argentina no fue la ausencia de conflictos, sino las dificultades para articular luchas que parecieron fragmentar los reclamos. Dicha fragmentación fue producida-entre otros factores- por los diferentes ritmos
} 
una vieja denominación, la Coordinadora de Derechos Humanos, y la formación de la Coordinadora Antirrepresiva son antecedentes mediatos de la MTDHC pero también experiencias bien diferentes. Ambas tendrán escasa duración y presencia pública, pudiéndose rastrear en el espacio local sus acciones entre 1994 y 1995. La primera de ellas nucleaba a los organismos clásicos en Córdoba, previos a la conformación de H.I.J.O.S., y organizaciones sociales y gremiales afines ${ }^{12}$. La segunda tematizó estrictamente el avance del "Gatillo fácil" 13 como consecuencia del aumento de las condiciones de vulnerabilidad social y económica y de las respuestas estatales de criminalización de la pobreza, aunque también promovía acciones de solidaridad con conflictos relevantes del período (SOLIS, 2006). El colectivo antirrepresivo en Córdoba se constituyó como espacio político de las izquierdas (haciendo un uso amplio de este concepto), nucleando a sectores sindicales de tradición radicalizada - como la Unión Obrera Gráfica de Córdoba-, también activos en oposición al proceso privatizador-como el Sindicato de los trabajadores de Obras Sanitarias de la provincia (SIPOS) ${ }^{14}-$, y a partidos políticos, como Patria Libre ${ }^{15}$. Varias de las expresiones de las juventudes universitarias ${ }^{16}$ en sus

\footnotetext{
y espacios con los que se acometieron las reformas estructurales, afectando diferencialmente a los sujetos, sectores y regiones.

${ }^{12}$ La Coordinadora emergió en la década del ochenta, momento en el que se afirmaba en el espacio local el denominado sentido histórico de la cuestión de los derechos humanos, al sedimentar en ella las referencias a las sistemáticas violaciones producidas por el terror de Estado en el último tramo del gobierno civil (pregolpe) y durante la última dictadura cívico militar. Entonces reunía a las principales organizaciones del MDH. Su denominación desapareció públicamente a medida que se afirmaba la vía de la impunidad, configurada ésta por las políticas nacionales de gestión del legado de la dictadura y, en ocasiones, el colectivo Coordinadora contra la Impunidad apareció tematizando este tópico (SOLIS, 2011).

${ }^{13}$ Con esa expresión comenzó a reconocerse a determinadas muertes producidas por acciones de uso letal de la fuerza por parte de efectivos de seguridad, mostrando las continuidades en la violencia institucional y los nuevos rostros de la criminalización de la protesta, en un contexto de aumento del desempleo y de los costos sociales de las reformas estructurales en Argentina. La cuestión del gatillo fácil ya era tematizada en ciertos lugares desde fines de la década anterior, pero se intensificó a mediados de los noventa.

${ }^{14}$ Por entonces el gobierno privatizó la provisión de agua potable y estos trabajadores habían sido muy activos en la lucha por mantenerla estatal.

${ }^{15}$ Conformado a finales de la década de 1980, incluyó viejos militantes de la izquierda revolucionaria setentista con nuevas generaciones juveniles, mixturando legados de la izquierda y del ideario nacional popular.

${ }^{16}$ Un rasgo distintivo de Córdoba es su alto componente universitario. Históricamente ha sido una cuidad de recepción estudiantil y por ello su activismo ha tenido fuerte protagonismo en diferentes momentos.
} 
vertientes orgánicas de izquierda e independientes también estaban allí integradas, al igual que otras organizaciones sociales y culturales que de algún modo participaban de este universo político. Sin embargo, la continuidad de estos espacios no fue sostenida con idénticos nombres ni colectivos, tanto por motivos internos como por factores contextuales. En este sentido, piénsese en el abrupto cambio de escenario que sobrevino con la crisis financiera provincial originada en el Efecto Tequila ${ }^{17}$ que culminó con la renuncia anticipada del gobernador Eduardo César Angeloz ${ }^{18}$ y el adelantamiento de la asunción de Ramón Bautista Mestre, a mediados de 1995. Cabe aclarar que si bien ambos pertenecían a la Unión Cívica Radical (UCR) los estilos de gestión y la composición de sus agendas de gobierno fue palmariamente distinta, resituando a los actores y sus prácticas de negociación y confrontación hasta entonces desarrolladas. De igual modo, el traspaso entre ambos -mediado por la crisis- implicó un agudo proceso de conflictividad social y política con aumento de la represión hacia los sectores movilizados, con protagonismo de los trabajadores estatales, y de cierre de los canales de negociación. Pero volviendo a los orígenes de la Mesa de Trabajo es preciso situar no sólo este escenario provincial de crisis y represión como antecedente directo sino la conformación de H.I.J.O.S. en 1995, un acontecimiento parteaguas en la historia del activismo local pro derechos humanos (SOLIS, 2011; PUTTINI, 2020).

Por otra parte, como se expuso al inicio, el surgimiento de la Mesa requiere ser inscripto en un proceso más amplio de vuelta a escena de la cuestión de los derechos humanos tanto en su sentido histórico como en las resignificaciones que se fueron operando en paralelo a la agudización de la situación socio-económica y la pérdida o falta

\footnotetext{
${ }^{17}$ Denominación genérica para referir a una crisis financiera internacional del capitalismo que se inició en 1994 en México y que tuvo efectos en las economías ligadas a esas formas de reproducción del capital por valorización financiera. En particular, Córdoba sufrió los efectos de la crisis de manera severa.

${ }^{18}$ Angeloz, de la Unión Cívica Radical, fue el primer gobernador de Córdoba electo después de la última dictadura en 1983. Obtuvo la reelección en dos períodos más consecutivos, posibilitado esto por una reforma constitucional; finalmente tuvo que anticipar la entrega del poder a su sucesor, Ramón Mestre del mismo partido radical, en julio de 1995 por los efectos políticos que la crisis económica generó en la provincia.
} 
de efectivización de derechos antes garantizados. Desde nuestra reconstrucción histórica, su origen se vincula directamente con una acción de memoria del terror de Estado y de exigencia de verdad y justicia. Veamos entonces cuales fueron esos usos del pasado que convocaron su conformación a través de un ejercicio de memoria:

La Mesa de Trabajo por los Derechos Humanos de Córdoba surge al calor de la lucha de H.I.J.O.S. (Hijos por la Identidad y la Justicia contra el Olvido y el Silencio), de los Centros de Estudiantes Secundarios, y otros organismos de derechos humanos en 1998 como una necesidad frente a la impunidad de los genocidas ${ }^{19}$ sueltos y la complicidad de la justicia institucional, y en busca de una educación y un país distinto, donde como jóvenes pudiéramos participar y ser protagonistas de un futuro distinto. (MTDHC, 2006) ${ }^{20}$

En términos del devenir del tratamiento de las demandas del MDH, 1998 es un momento de aún persistencia de las políticas de impunidad pero con una creciente impugnación social a su continuidad. Por ejemplo, a inicios de ese año se logró derogar las leyes de Punto Final y Obediencia Debida, aunque sin carácter retroactivo; mientras los indultos seguían vigentes (SOLIS, 2012). En el ejercicio de memoria de la Mesa se tomaba como hito fundacional el año 1998 en que un conjunto de organizaciones realizó un escrache novedoso al referenciar la represión en la educación, apuntando a un ámbito y una modalidad particular: "El escrache realizado a Transito Rigatuso, quien entregó listas de estudiantes secundarios del Colegio Manuel Belgrano, (hoy desaparecidos) a los personeros de la dictadura militar, fue el punto de partida de un camino de 7 años" (MTDHC, 2006).

\footnotetext{
${ }^{19}$ Expresión para referir a los responsables de la represión.

${ }^{20}$ Presentación de la Mesa en su página institucional web vigente en 2009. Mesa de Trabajo por los Derechos Humanos. Espacio colectivo de articulación y participación política en lucha por los Derechos Humanos. Viernes 9 de junio de 2006.

Disponible en http://www.derechoshumanoscba.org.ar/spip.php?article2079 [Consulta: junio de 2009]. Este documento web es referenciado en el artículo como MTDHC, 2006. En la actualidad la Mesa posee desde 2019 otra página web institucional, allí se indica como fecha de conformación el año 1999. Ver publicación de presentación institucional. MTDHC, 2020.

Disponible en: https://mesadetrabajoporlosddhhdecordoba.com.ar/contenido/82/mesa-de-trabajo-por-losderechos-humanos-de-cordoba-quienes-somos [Consulta: 9/6/2020]
} 
El escrache se convirtió en el formato de protesta típico del MDH desde la conformación de H.I.J.O.S. y fue replicado en sus diferentes regionales. Es una protesta y, a la vez, una performance política que señala a los impunes por sus crímenes. Es un modo de señalar públicamente la falta de justica y de procurar la condena social. Volviendo a la cita, si bien el escrache se repitió en años posteriores, incluso ampliando el repertorio de recordación, ${ }^{21}$ la primera ocasión sirvió para inscribir una clave de memoria local, al señalar la responsabilidad del ex director de la Escuela Superior de Comercio Manuel Belgrano ${ }^{22}$ en la represión y posterior asesinato y/o desaparición de estudiantes secundarios en la etapa pregolpe. Por entonces se visualizaba a la agrupación H.I.J.O.S. como referente principal de la actividad, junto a centros de estudiantes secundarios y organizaciones varias ${ }^{23}$. Estos organizadores también se relacionan con los espacios con que H.I.J.O.S. trabajaba decididamente. Su interés por las juventudes -entre las que se reconocía- y por el tratamiento escolar de la cuestión es de larga data. En eso recupera una tradición del $\mathrm{MDH}$ de vincularse tempranamente con las escuelas para ofrecer charlas, talleres o participar de acciones conmemorativas para contar su experiencia. Con la incorporación de los hijos, este enlazamiento con las juventudes es más vigoroso. Y la problemática de la trasmisión entre generaciones también se vuelve

\footnotetext{
${ }^{21}$ En 1999 las crónicas refieren una serie de actividades conmemorativas: charla debate en el colegio Manuel Belgrano, escrache a Rigatuso y marcha a la plaza San Martín. En la oportunidad se difundió un volante con los nombres de los 11 estudiantes desaparecidos y con un informe detallado de la responsabilidad del denunciado en los actos represivos.

${ }^{22}$ Se trata de una escuela secundaria dependiente de la Universidad Nacional de Córdoba. Con fuerte protagonismo en el ciclo de radicalización de los años sesenta y primeros setenta, fue también escenario del despliegue represivo. Una nota de memoria singular es que varios de sus estudiantes resultaron desaparecidos, muchos de ellos de activo compromiso estudiantil y político. La actual presidenta de Abuelas de Plaza de Mayo en Córdoba, Sonia Torres, es madre de una exalumna desaparecida embarazada que había egresado de esa escuela, Silvina Parodi. Otros integrantes del MDH son también egresados de esa generación.

${ }^{23}$ I. Morán afirmaba que H.I.J.O.S., "partidos de izquierda, alumnos y egresados del Manuel Belgrano, víctimas de la represión y otras organizaciones de DD.HH" protagonizaron el escrache. Reporte especial "La verdad señala a sus verdugos", en La Hendija. Córdoba, Año 1, n. 3, 1998, p.13. Esta publicación fue parte de ese proceso de politización de las juventudes universitarias; era una iniciativa periodística ligada a estudiantes de comunicación que se referenciaban en el arco del amplio espectro de juventudes opositoras al gobierno de Carlos Saúl Menem y sus políticas educativas.
} 
más presente. Entendemos que desde allí puede avizorarse el empeño puesto en tematizar la represión en el ámbito educativo de la escuela secundaria, trabajando con una comunidad altamente sensibilizada por su propia historia y los trabajos de memoria que realizaba.

En efecto, en la historia local del terror de Estado, el caso de los estudiantes secundarios represaliados del Belgrano es paradigmático y se ha convertido en un símbolo de la complicidad de las autoridades pregolpe y la represión dictatorial, temática que los propios organismos y sus aliados han contribuido a inscribir en agenda, por ejemplo, con el escrache mencionado ${ }^{24}$. Incluso en aquellos años contemporáneos a los sucesos represivos, los mismos familiares de los estudiantes fueron activos impulsores de la verdad y la justicia, denunciando públicamente los hechos ${ }^{25}$. En definitiva, en las acciones de memoria, la Mesa reconocía esta acción de protesta como un hito fundante de esta conformación de un espacio intraorganizacional. Allí encontraba su legitimación pública, con una acción que se pretendía disruptiva al tematizar la complicidad civil con la dictadura y la represión a las juventudes de escuelas secundarias. Esta acción representaba asimismo la potencialidad del escrache para señalar la ausencia de justicia no sólo con los responsables militares sino también con sus apoyos civiles.

\section{Las ocasiones y la dramaturgia}

\footnotetext{
${ }^{24}$ Una acotación ineludible para los que no son de Córdoba es recordar que aquí la represión comenzó mucho antes del Golpe, tal como lo han denunciado sistemáticamente los organismos y sus aliados en la esfera judicial y como lo confirman los estudios académicos sobre el período. Cfr. Informe CONADEP Delegación Córdoba, 1999; SERVETTO, 1998 y 2004; OVIEDO y SOLIS, 2006. Este adelantamiento represivo ha sido también constatado en otros escenarios, lo que no impide mantener a 1976 como hito en el cambio cualitativo y cuantitativo de la represión. Ver, al respecto, la abundante producción de la historia de la represión en Argentina, en especial dentro de la denominada historia reciente. Para visiones de síntesis de estos avances, se sugiere la producción de Gabriela Águila, entre otros.

${ }^{25}$ A principios de julio de 1975, los padres de alumnos publicaban una solicitada en el diario local de mayor tirada denunciando la responsabilidad de Tránsito Rigatuso y Hugo Lafranconi en la elaboración de listas. La Voz del Interior, 2 julio 1975. Una periodista local escribió un libro ficcionalizado pero con importante documentación inédita de época, ver MARIANI, 2006.
} 
Desde sus comienzos, la actividad de la Mesa se ha orientado a participar activamente como promotora, organizadora y garantizadora de una serie de eventos públicos que remiten al tiempo de las conmemoraciones y que podríamos caracterizar como la conformación de una agenda fija en el calendario rememorativo. Desde la perspectiva del uso político de las calles, este se complementa con otro, más eventual o coyuntural podríamos decir, que se liga a la puesta en agenda de conflictos puntuales como así también a la apertura de ciertas ventanas de oportunidad ligadas al impacto de acontecimientos generados por otros actores (el estado, la justicia, los colectivos y sus luchas, etc.). Aquí se hace referencia a los primeros, el repertorio fijo de conmemoraciones, que se compone para esta segunda mitad de los años noventa y primeros años dos mil de tres momentos que se han ido construyendo incluso desde antes de la conformación de la Mesa: a) los 24 de marzo, fechas de aniversarios del Golpe de Estado producido en 1976 y que comenzaron a ser conmemorados desde 1984, ya con el retorno democrático; b) los 16 de septiembre que conmemoran el episodio represivo conocido como "la Noche de los Lápices" ${ }^{26}$ y, por último, c) los 10 de diciembre, aniversario de la Declaración Universal de los Derechos Humanos de la Organización de las Naciones Unidas (O.N.U.) ${ }^{27}$.

La primera consideración remite a la incidencia recíproca entre las modalidades predominantes de las demostraciones públicas y las características de las estructuras de movilización. En efecto, en la historia reciente de tales fechas se encuentran tendencias a la ritualización de las conmemoraciones, construyéndose progresivamente cierto repertorio de recordación, entendido éste como la estabilización del formato de acción (tipo de actividad, modalidad de ocupación del espacio) y también de quienes son los

\footnotetext{
${ }^{26}$ Esta fecha refiere a un acontecimiento represivo acometido contra estudiantes de la ciudad de La Plata, en plena dictadura. Sobre las memorias de este acontecimiento represivo, ver RAGGIO, 2017. En Córdoba fue resignificado aludiendo a los episodios locales de represión a los estudiantes.

${ }^{27}$ Respecto a los 24 de marzo y los 10 de diciembre hemos trabajado sobre toda la década de los noventa, desde los indultos hasta la crisis del 2001. Sin embargo, hasta ahora no habíamos analizado en profundidad la participación de la Mesa. Cfr. SOLIS, 2009; 2011
} 
promotores de las mismas; incluso en la difusión de determinados componentes enmarcadores. Respecto a los modos de conmemorar públicamente y a sus sostenedores, desde su constitución, el lugar de la MTDHC debe destacarse por cuanto terminó configurándose en el colectivo referente principal (aunque no el único, sobre todo de la última fecha) de la organización de los tres eventos, en un proceso que precisa ser aludido en asociación con su conformación como espacio de articulación permanente que tuvo y tiene en la actualización del sentido histórico de las luchas por los derechos humanos su marco común predominante.

Entonces, la MTDHC actuaba de algún modo como colectivo que promueve y sostiene determinadas demostraciones públicas y, a su vez, esta labor le permitió convertirse en un espacio permanente por cuanto se estableció un calendario fijo de acciones y se generaron lazos y redes de acción que se presentizaron en cada ocasión. En consecuencia, se convirtió progresivamente en un sostenedor de acciones de memoria, ganando en recursos organizativos y simbólicos que se tradujeron en legitimidad política. Esas tareas políticas en la agenda conmemorativa incluían fuertes apuestas. Sobran los ejemplos que dan cuenta del tiempo dedicado por las organizaciones a garantizar cada acción: desde acordar las modalidades, generar los fondos, consensuar los documentos, conseguir las adhesiones, difundir en la prensa y "poner el cuerpo" a las actividades. De allí que, en conversaciones del trabajo de campo, un integrante de H.I.J.O.S. aludiera a la centralidad que los 24 de marzo siguen teniendo en la agenda de los organismos al comentarnos que, tras aquella fecha, padecía lo que ellos mismos denominan "síndrome pos $24 " 28$. Lo que ponemos de relieve es la mutua incidencia entre las ocasiones y las formas organizativas.

\footnotetext{
${ }^{28}$ Referencia en conversación informal con integrante de H.I.J.O.S. Para quienes compartimos espacios de interacción con ellos, la agenda de cuestiones y tareas comunes implica cada año considerar la alta intensidad de trabajo que implica en sus labores la conmemoración de cada 24 de marzo.
} 


\section{Las definiciones}

"Espacio colectivo de articulación y participación política en lucha por los Derechos Humanos "29

En el plano del activismo local, la necesidad de articulación política se convirtió en un desafío común de la mayoría de las organizaciones activadas en los noventa, sobre todo en la segunda mitad de esa década, cuando se hicieron más visibles los costos sociales de las reformas estructurales. Así, desde iniciativas de articulación suprasindical y de alianzas partidarias hasta los múltiples intentos de traducir electoralmente las luchas, sostenemos que en cada análisis resulta pertinente indagar empíricamente en qué consiste tal aspiración. En otras palabras, la vocación de constituir un espacio de articulación y participación política que expresa el inicio de este apartado como un posicionamiento de la Mesa debe ser repensada en términos de las culturas políticas recientes. Entonces, no sólo es preciso tener presentes las grandes transformaciones estructurales de las últimas décadas en Argentina y sus efectos en términos de constitución de una sociedad excluyente (SVAMPA, 2005), sino también valorar la incidencia de estos cambios en todo un reservorio de modos de hacer y pensar la política que se vieron drásticamente confrontados con la configuración de una situación inédita y cuyo impacto puede leerse también en claves de militancia. ¿Qué, quiénes y cómo articular? ¿A qué refieren con participación política? ¿Cómo la entendían? Si bien estas preguntas merecen respuestas dinámicas, ya que los colectivos y sus organizaciones sostienen diferentes modos de acción y definiciones en su devenir, es preciso especificar cuáles fueron los significados compartidos en esos primeros tiempos de la Mesa. Lo que queremos señalar es que no se trataba de una voluntad retórica sino de un itinerario de prácticas y discursos que han abonado el espacio público local con, por ejemplo, nuevos modos de referir esquivos

\footnotetext{
${ }^{29}$ Eslogan identificatorio del sitio web de la Mesa de Trabajo por los Derechos Humanos de Córdoba, fechado el 9 de junio de 2006, disponible en:

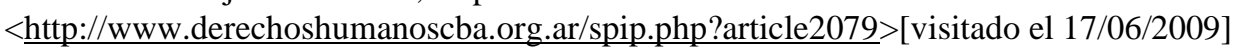


pasados. En este sentido, la MTDHC comparte así el espacio más amplio del activismo local que desde 1994/5 abonó un retorno interpretativo a los múltiples pasados que dotaban de sentido la experiencia, produciéndose por esta vía una de las rupturas principales con las retóricas de fuga -futuristas de algún modo- y de claro corte con el pasado, que se habían erigido en dominantes desde los años ochenta democráticos y, más, en los noventa. En esta línea, se legitimaban trazando una genealogía de luchas que permite alumbrar empíricamente el trabajo de articulación política que los definió. Vemos el itinerario:

\begin{abstract}
De esas actividades y luchas es importante resaltar algunas de ellas como hitos de construcción y cambio, en que las organizaciones que formamos partes de la Mesa de Trabajo por los Derechos Humanos de Córdoba fuimos actores: La lucha por la Defensa de nuestro patrimonio provincial, la Empresa de Provincial de Energía de Córdoba, el Banco de la Provincia de Córdoba y la Lotería Provincial, que quisieron ser privatizadas por los gobiernos liberales. La lucha por Otra Educación, el repudio a las políticas de represión y de Tolerancia Cero, el pedido de Juicio y Castigo a los genocidas y sus cómplices, la lucha contra la impunidad de los asesinatos de niños durante las jornadas del 19 y 20 de diciembre del 2001, el acompañamiento a los campesinos en sus exigencias de Tierra, Trabajo, Agua y Justicia entre otras, forman parte de nuestras demandas, de nuestras búsquedas y logros. (MTDHC, 2006)
\end{abstract}

Una referencia obligada es contextualizar esas redes de conflicto. La defensa del patrimonio provincial fue el marco en el que se encuadró la resistencia a los proyectos privatizadores de empresas públicas provinciales, proveedoras de servicios estratégicas (como la Empresa Provincial de Energía de Córdoba) y de la banca pública, sistemáticamente ensayados por los gobiernos provinciales tanto radicales como peronistas, partido que asumió con una alianza más amplia el gobierno de la provincia y la ciudad desde fines de 1999, rompiendo la hegemonía electoral de la U.C.R. conseguida desde las elecciones fundacionales de 1983. La lucha por "otra educación” refiere a la crisis del sistema educativo y su rechazo al modo en que los sucesivos recortes presupuestarios la tematizaban como un problema de gasto público, particularmente evidente en la gestión del gobierno nacional de la Alianza, fuerza política que ganó las elecciones nacionales de 1999. Estos recortes a la educación fueron particularmente 
severos por las medidas propuestas por el ministro de economía Ricardo López Murphi. La tolerancia cero remitía a la criminalización de la pobreza que, como política de Estado, implicó una particular respuesta al problema de la "inseguridad" a través de la represión del delito. En Córdoba, el gobernador José Manuel De la Sota asumido en 1999 puso en acción un plan policial bajo el nombre de Comando de Acción Preventiva (C.A.P) que se basaba en mostrar ostensiblemente la presencia policial en las calles de la ciudad. La contracara de esta política fue el aumento de las situaciones de violación a los derechos de los grupos vulnerables, las requisas a los jóvenes, las denuncias por abuso policial y por los operativos "por portación de rostro", cada vez más frecuentes en los barrios populares de Córdoba ${ }^{30}$. La política de seguridad delasotista se complementó con la erradicación de "villas de emergencia" a los barrios-Ciudad, novedosas urbanizaciones en zonas muy alejadas, con servicios insuficientes y precaria infraestructura. También reconocían como esfera de acción la lucha de los campesinos contra las usurpaciones que la extensión de la frontera agrícola produjo en el campo cordobés. Las muertes en torno al 2001 hacen referencia a las producidas en el contexto de las protestas del 19 y 20 de diciembre que terminaron con la renuncia del presidente Fernando De la Rúa de la Alianza. En Córdoba, como consecuencia de la represión en los barrios populares, fue asesinado por un disparo policial David Moreno, de 13 años de edad, una de las 39 víctimas por la represión en todo el país.

Volviendo al análisis de conjunto de la genealogía propuesta, el dato principal es que la misma tiene a la Mesa como agente del presente, es decir que los redactores de este documento no apelaron a luchas pasadas sino a otras contemporáneas, las que habían vivido y de las que habían sido parte. Por lo tanto, remiten a una lectura del pasado presente marcando su intervención en los conflictos claves de la provincia, entre los que se destacan el rechazo a la política de privatización de empresas estatales y la adhesión a una concepción ampliada de los derechos humanos como paradigma de su construcción

\footnotetext{
${ }^{30}$ Esto llevó a que, en el rumor popular, la C.A.P. fuese rebautizada como "Comando Anti Pobre". 
de agenda. En relación al primero, la participación de la MTDHC en el rechazo a las reformas impulsadas desde la llegada de De la Sota a la administración provincial en 1999 incluyó la denuncia pública del pasado de Germán Kammerath, intendente de origen liberal -integrante de la alianza oficialista- que tuvo un pasado más que oscuro y cuyo desempeño terminó en un intento de revocatoria. Un volante de la MTDHC titulado "Germán Kammerath lo denunciamos" historiza sus vínculos con la dictadura y diversos episodios de corrupción en los que estaba siendo investigado, desde la compra de su título universitario hasta su gestión como Secretario de Comunicaciones de la Nación bajo el Menemismo. De aquel tiempo es conocida en Córdoba su cercanía y activa participación en el otorgamiento de licencias a operadores radiales que, a la postre, permitieron la concentración de medios y el cuasi monopolio informativo que, por ejemplo, sustenta una conocida emisora radial local ${ }^{31}$. Retomando la denuncia, esto muestra una especificidad de su labor: las actualizaciones de un cierto pasado como ejercicio de memoria no remiten solamente a los crímenes impunes del terror de Estado como cuestión ni a los años setenta como tiempo exclusivo: otros pasados, a veces más cercanos temporalmente pero más distantes en términos de presencia en agenda, son convocados para legitimar posicionamientos públicos sobre asuntos comunes. Con relación al segundo aspecto, dijimos en la introducción que este es un elemento central de su definición: la incorporación de una perspectiva ampliada de la agenda de los derechos humanos ha sido aquí menos problemática que en espacios más tradicionalmente ligados al espacio del activismo pro derechos humanos. Desde allí se compone un trabajo político de articulación con actores variados, de diversos grados de institucionalización que tenían

\footnotetext{
${ }^{31}$ No escapa a nuestro análisis que el referente periodístico principal de la misma, a principios de los noventa -cuando conducía un programa televisivo de entretenimiento por el canal universitario- entrevistó largamente al ex general Luciano Benjamín Menéndez y no desde una perspectiva crítica precisamente. Cuando fue el tiempo de la movilización por la revocatoria del intendente, varios medios locales invisibilizaron esta lucha como hecho periodístico. La revocatoria fue finalmente impedida a través de una serie de artilugios legales y consensos políticos (detrás de escena) con que se obturaba aquel clima destituyente en Córdoba. Sin embargo, la ganancia en términos de conformación de redes y circulación y ampliación de sectores activos fue importante.
} 
en común protagonizar "luchas" contra el modelo. Por consiguiente, si bien existe una adhesión expresa a la Declaración Universal de los Derechos Humanos, lo interesante es que en el mismo proceso de activación se van definiendo causas, conflictos, espacios y actores que se tornan inteligibles al amparo de la retórica de los derechos humanos lo que, desde nuestra posición teórica, supone una concepción constructivista de los derechos humanos a la manera de Reiner Forst (2005) cuando postula el derecho a justificación, entendido como la posibilidad de dar o exigir razones acerca de un determinado orden de cosas, en tanto presupuesto central de esta línea que intenta despegarse de posiciones que acotan su significación al mundo del derecho y su tratamiento jurídico.

Esa construcción inacabada del sentido de los derechos humanos tenía una fuerte inscripción contextual. La lucha contra el modelo, la necesidad de un cambio y de construir una alternativa horizontal, tanto como la falta de contención de los partidos políticos fueron tópicos recurrentes en actividades internas de la Mesa en esta etapa formativa y de consolidación inicial. De este modo, esa construcción del sentido de los derechos humanos se realizaba desde la evaluación de las propias prácticas y conflictos en los que las organizaciones miembros operaban, contribuyendo a instituir un sentido dinámico del marco de los derechos como argumento de legitimación de las luchas contemporáneas, con una marcada vocación por generalizar demandas hacia la definición de órdenes deseables alternativos.

\section{Las prácticas políticas}

Ahora bien, desde una perspectiva integradora de la noción cultura política su abordaje implica detenerse en las representaciones del orden social y político, las áreas o problemas sobre los que se debe intervenir, los marcos culturales que significan los problemas que se inscriben a debate pero también, y fundamentalmente, las prácticas políticas que los sujetos realizan. En el momento de su conformación y consolidación 
como espacio interorganizacional, la propia definición de "Mesa" implicaba ya un posicionamiento diferencial con otras modalidades de articulación de espacios políticos que se venían desarrollando en la provincia: esto es, las coordinadoras y, más anteriormente, las comisiones. Si bien las primeras remiten a espacios de coordinación intersectorial de carácter permanente y cuyos integrantes, generalmente, podían tener poder de veto sobre las resoluciones; las segundas lo hacen de manera preferencial a espacios de coordinación no permanentes, asociados a objetivos específicos y por ello caracterizados por su poder resolutivo ${ }^{32}$. En cambio, la Mesa como modalidad organizativa tenía en Córdoba antecedentes bien concretos, ligados -por ejemplo- a la lucha de los sectores combativos en la etapa pregolpe, como la Mesa Provisoria de Gremios en lucha, la que resultó fundamental en la tarea de inscribir públicamente el avance represivo aún antes de efectivizarse el golpe de Estado de 1976, incluso el formato había prosperado en los años ochenta bajo otros objetivos ${ }^{33}$. Es decir que los materiales de la organización política actualizaban formas organizativas que habían sido parte de las modalidades del compromiso político de los años setenta predictatoriales y de la etapa posdictadura. Allí, la trasmisión entre generaciones habilitaba la recreación de formas usuales de organización pero resignificadas en urgencias nuevas.

\footnotetext{
${ }^{32}$ En la historia reciente de Córdoba, numerosas comisiones y coordinadoras habían tenido existencia. Como comisión surgió tempranamente el espacio de los familiares de secuestrados y desaparecidos y se hizo pública en enero de 1976, revitalizando el nombre de las anteriores comisiones de presos, características de una etapa represiva previa. A su vez, las coordinadoras fueron frecuentemente las modalidades organizativas de la etapa democrática: contra la impunidad, antirrepresiva y las estrictamente sindicales, por citar sólo las de mayor relevancia pública.

${ }^{33}$ Así, el 16 de setiembre de 1975 La Mesa provisoria de Gremios en Lucha se movilizó en homenaje a "los compañeros A. López, J. Varas y Curuchet en el aniversario de su asesinato", proclamando en una solicitada que "Con la destitución de Lacabanne no alcanza, la lucha continúa." Entre sus exigencias destacaban los 8 puntos que sintetizaban el avance represivo en la provincia: "Inmediata liberación a los presos por causas políticas y gremiales. Levantamiento de órdenes de captura a los dirigentes gremiales. Repudio a los traslados a otros penales. Devolución de los sindicatos intervenidos de Luz y Fuerza y SMATA [sindicato de los mecánicos]. Investigación de los crímenes, torturas y desapariciones efectuadas por grupos parapoliciales y cese inmediato de persecuciones y allanamientos a delegados, activistas y dirigentes gremiales y políticos." La Voz del Interior, 15 octubre 1975, p. 8. En los años ochenta democráticos, en la posdictadura, también se organizaron mesas, por ejemplo en relación a la organización de los barrios ante la urgencia de la normalización.
} 
Ahora bien, un rasgo de identidad del espacio de la Mesa de Trabajo fue propiciar y apostar a sostener un trabajo caracterizado por la horizontalidad entre sus miembros, rasgo típico de algunas culturas políticas juveniles en transformación de la que ésta era una de sus expresiones. En otras palabras, la voluntad de trabajo horizontal como modalidad de construcción política no resultaba meramente declamativa, a la luz de las formas organizativas en las que el mismo se materializaba. Pues, fuera del calendario rememorativo que visibilizaba las acciones de protesta que actualizaban las demandas de justicia, verdad y memoria, la Mesa se fue constituyendo como un espacio de trabajo más permanente, llegando a tener reuniones semanales y efectivizando plenarios anuales en los que se evaluaba la tarea realizada, se elaboraban prolijos diagnósticos de situación y se consensuaban líneas de trabajo que, generalmente, apuntaban a la implicación activa de la Mesa en conflictos que tematizaban una concepción amplia de los derechos humanos, y al mejoramiento y la operatividad el espacio. Particularmente, los plenarios cristalizaban un saber hacer de la política muy diferente de aquel que dominaba en las organizaciones partidarias preponderantes, usualmente organizadas de manera jerárquica. Los plenarios anuales de la Mesa se concebían como un espacio de trabajo multiorganizacional en el que las definiciones eran trabajadas desde la primacía de la modalidad del taller -con el énfasis en la circulación de la palabra y la disposición a la escucha- que dotaba a todos sus participantes de una pretendida igualdad enunciativa ${ }^{34}$. Bajo la fuerte impronta de la dinámica de taller, sustentada ésta en la perspectiva de la educación popular ${ }^{35}$, los plenarios dinamizaban momentos de reflexión al interior de cada

\footnotetext{
${ }^{34}$ Este análisis no oculta la dimensión conflictiva. De hecho, en entrevistas informales con miembros de la Mesa se trasluce que las definiciones acordadas mayoritariamente no siempre resultaban las esperadas por todos. En particular, las demandas de posicionamiento y acción política que remitían a conflictos o iniciativas particulares de los colectivos no se procesaban rápidamente. Esto ocurrió, por ejemplo, cuando los Autoconvocados postulaban la necesidad de sumar la Mesa a su estrategia de impulsar una Ley de Emergencia Social. En un contexto de aumento de la conflictividad social y política, como fue el año 2001, en el espacio de la Mesa repercutían las urgencias que los énfasis de cada lucha sectorial intentaban imprimirle.

${ }^{35}$ La educación popular es igualmente parte de ese acervo trasmitido entre generaciones. Entiendo que en los talleres y otros modos de procesamiento de la cuestión de los derechos humanos que el propio MDH fue recreando en diferentes momentos, la educación popular cumplió un rol orientador de las prácticas muy
} 
organización y otros de trabajo interorganizacional, buscando así afianzar redes de afinidad, sociabilidad y reconocimiento ${ }^{36}$. La existencia de coordinadores, la alternancia del trabajo en pequeños grupos o comisiones con instancias plenarias y la presencia de registradores que documentaban las discusiones y los acuerdos muestran la particularidad de un espacio que congregaba a organizaciones viejas y nuevas, con diferentes perfiles, ocupadas en acentuar rasgos de encuentro y confluencia en las miradas, las lecturas políticas y las estrategias de acción. Esta somera descripción del trabajo puertas adentro de la mesa no se propone como idílica y consensualista. Por el contrario, el conflicto, o al menos la diferencia, era frecuentemente albergada en la discusión; incluso puede afirmarse que si bien no todos los integrantes se mantuvieron dentro de la Mesa, se daba importancia a las instancias de discusión para intentar lograr acuerdos.

Fue precisamente en el marco de este trabajo, en ocasiones invisibilizado a los ojos del analista acostumbrado a mirar su inscripción pública bajo el sesgo de la acción colectiva de protesta, donde se reconoce el tiempo trabajoso de lograr acuerdos que superasen las definiciones más cortoplacistas o las ligadas directamente a las ocasiones para protestar conmemorando. Ese otro tiempo, que Scott (2000) conceptualiza como infrapolítica -no en sentido peyorativo sino porque no acude aquí necesariamente la inscripción pública y mediática- es sumamente necesario para comprender, por un lado, la supervivencia temporal de la Mesa y, por otro, la "cocina" de las definiciones y de las prácticas y sus mutuas implicancias. En este sentido, rescatar la labor de performance política que este tiempo de las organizaciones revela deviene constitutivo para analizar con mayor asidero el tiempo de la cólera. A su vez, es desde la construcción política

significativo. Esta vertiente fue retomada por las/os H.I.J.O.S. para sus trabajos internos como agrupación y también para los talleres que realizaban en escuelas y organizaciones. La MTDHC recupera y amplia esas tradiciones al articular a otros colectivos que también venían participando de formas de educación popular.

${ }^{36}$ Se destaca el aporte en la construcción de las modalidades de encuentro de las organizaciones que asumían para sí esta perspectiva. Me refiero particularmente al necesario estudio pendiente de determinados actores que tenían ya una larga tradición en trabajar con estas dinámicas, como por ejemplo la Universidad Trashumante. 
entendida como proceso de politización que se torna más comprensible la apertura de las ocasiones para protestar que, a lo largo de su funcionamiento, se observa como otro rasgo característico de la Mesa. En particular, me refiero a las intervenciones políticas concretas que desarrollaron en otros conflictos paradigmáticos de ese convulsionado fin de siglo, como la luchas contra los proyectos privatizadores que desplegó la intención de aplicar una suerte de menemismo tardío desde la llegada del gobernador de la Sota a la provincia en 1999.

\title{
Los integrantes y los nuevos contornos de la militancia
}

Un rasgo distintivo de la Mesa en esta etapa es la amplitud de integrantes que la componen, registrándose una tendencia al crecimiento de los mismos, en el doble registro de las adhesiones como de las participaciones activas. Tal distinción resulta pertinente para discriminar, hasta donde sea posible, el grado de afectación e involucramiento que las organizaciones tuvieron con la MTDHC ${ }^{37}$. Así, del núcleo inicial conformado por los organismos derechos humanos y agrupaciones estudiantiles secundarias y universitarias, el espacio autodefinía sus integrantes de esta manera en 2006:

\begin{abstract}
Muchos han sido los caminos recorridos en estos siete años de resistencias, luchas y transformaciones, en ellos nos hemos encontrados diversas organizaciones de todos los sectores sociales (centros de estudiantes universitarios y secundarios, sindicatos y organizaciones barriales, organismos de derechos humanos y ambientales, bibliotecas populares, músicos y artistas, murgueros y poetas, campesinos y desocupados, etc.) entendiendo que solo a través de la diversidad, el consenso y la horizontalidad de nuestra práctica

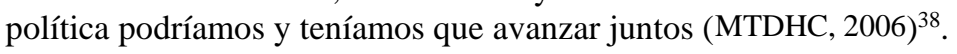

\footnotetext{
${ }^{37}$ Como suele ocurrir en estos espacios de encuentro interorganizacionales, una preocupación constante de sus miembros ha sido igualar el involucramiento en los definidos como asuntos comunes, buscando superar la antinomia entre las organizaciones que efectivamente sostienen la labor de la Mesa y aquellas que tienen una participación más esporádica.

${ }^{38}$ En el sitio web se colocan como integrantes las siguientes organizaciones de las que se presentan extractos de sus definiciones identitarias y prácticas políticas: Universidad Trashumante, Cátedra de Psicología Comunitaria (UNC), Sindicato de Obras Sanitarias y Casa de los Trabajadores, La Bisagra (Movimiento Estudiantil Universitario), Abuelas de Plaza de Mayo, H.I.J.O.S., Comisión contra el desalojo
} 
La ampliación y heterogeneidad de sus integrantes es un dato del proceso más general de vuelta a escena de los derechos humanos tanto en su sentido histórico como en sus resignificaciones. En 2009, los organizadores estimaban en más de 100 las organizaciones que conformaban la Mesa. Caben aquí varias lecturas. En primer lugar, la MTDHC se convirtió en un espacio convocante para organizaciones muy variadas pero en las que domina el activismo juvenil, permitiéndonos entonces recorrer cuáles los espacios y modalidades de politización de las generaciones jóvenes de fines de la década de los noventa y los primeros de los dos mil. Allí se observa la preponderancia que adquirió la militancia política, social y cultural, preferentemente en espacios novedosos y por fuera de agrupaciones más tradicionales, como los partidos o los sindicatos, pero que también se incorporaron al amplio espectro de la Mesa.

Al respecto, conviene matizar las diferencias entre los tipos de militancia, al menos si se considera que los propios activistas suelen realizar usos blandos de tales definiciones al momento de nominar sus prácticas. Es poco probable que los colectivos culturales no visualicen como políticas sus prácticas, al tiempo que las dimensiones lúdicas y festivas se han convertido en indispensables en la realización de las performance políticas contemporáneas ${ }^{39}$. Y este sí pareciera ser un rasgo distintivo de la politización juvenil ${ }^{40}$. Por ejemplo, en uno de los plenarios de la Mesa, se sacó entre las conclusiones realizar un llamamiento al Movimiento Artístico de Córdoba, al tiempo que se evaluaba la necesidad de renovar las formas de la protesta.

de Villa La Maternidad, Red Buhito (Defensa de los derechos de 1@s Niñ@s y 1@s Adolescentes), Familiares de Desaparecidos y Detenidos por Razones Políticas de Córdoba.

${ }^{39}$ Ello es particularmente notorio en los repertorios utilizados: "Escraches y homenajes, recitales y murgueadas, charlas y jornadas culturales, cartillas, talleres de educación popular, actos y movilizaciones, cortes de ruta y denuncias, pintadas y murales, nos encontraron y nos encontraran en las calles, en las aulas, en los barrios y casas, en los sindicatos y centros vecinales con la certeza de que no nos han vencido porque tenemos 30 mil razones para seguir luchando" (MTDHC, 2006).

${ }^{40}$ Claro que un análisis más profundo de este punto implicaría considerar las mutaciones que se vienen produciendo en las nuevas generaciones no sólo en el campo de las subjetividades sino de su relación con el arte, los objetos y su propio cuerpo, temáticas que exceden ampliamente el carácter aproximativo de este trabajo. 
Ahora bien, la segunda reflexión desde el punto de vista de su composición histórica es que originariamente podría inscribirse como una iniciativa marcadamente juvenil, pero que a la postre se ha convertido en un espacio en el que conviven militantes de diferentes generaciones: no sólo por la integración de otros organismos clásicos del $\mathrm{MDH}$, sino también por aquellos provenientes de espacios sindicales o colectivos con marcada presencia en el trabajo territorial, por ejemplo. De hecho, la ampliación de sus integrantes se exhibe también en la presencia creciente de los productos comunicacionales de la MTDHC (por ejemplo: volantes, afiches, convocatorias y declaraciones) en esos lugares más tradicionales de los modos del involucramiento político. Ello también se relaciona con modificaciones en las culturas políticas de los noventa; en perspectiva, podríamos decir que, siempre para el plano cordobés, se observa un proceso de crisis y alejamiento de las juventudes respecto a los espacios de activación tradicionales hasta la primera mitad de los noventa, de la mano de la crisis de las izquierdas y también de la política partidaria, traducida ésta por ejemplo en la pérdida de gravitación de las juventudes partidarias que habían sido protagónicas desde los años finales de la dictadura hasta los indultos y el advenimiento del estilo ejecutivista que impregnó a la profesionalización de la política y tuvo su máxima expresión en el menemismo ${ }^{41}$.

Sin embargo, desde mediados de los noventa, el mapa del activismo local se fue renovando: por un lado, por la nueva presencia de organizaciones partidarias de izquierda que revitalizan la vertiente político-partidaria, con cabida principalmente entre los estudiantes secundarios y universitarios. Claro que sus relaciones con la MTDHC no han sido fáciles, produciéndose conflictos en la conformación de los temas de agenda de la Mesa como en los contenidos y significados de las actividades emprendidas, sobre todo en las lecturas políticas que acompañan cada conmemoración pública de los 24 de

\footnotetext{
${ }^{41}$ Hemos trabajado el efecto desarticulador que tuvo la conjunción de ambos fenómenos en SOLIS, 2011.
} 
marzo $^{42}$. Por otra parte, ciertos espacios sindicales, sean los activados por exclusivos conflictos sectoriales - como los intentos privatizadores- u otros de trayectorias más afines a los planteos de la Mesa, se han incorporado progresivamente. De todos modos, la amplitud de miembros no significa que todas las organizaciones mantengan idéntica participación; la irregularidad de las presencias también es una constante de estas iniciativas de articulación en las que el propio tiempo de las organizaciones suele obstaculizar la asiduidad con que asisten a las reuniones o se comprometen en las actividades promovidas. Sí se puede mencionar un grupo activo más permanente, dentro del cual resalta el lugar de la agrupación H.I.J.O.S. Regional Córdoba, uno de sus promotores fundacionales.

Hacia fines del siglo pasado, en uno de sus plenarios, más de 140 militantes de 42 organizaciones participaron, en el año 2000 del encuentro evaluativo. En aquel año, como en el 2001, uno de los slogans sintetizadores de su posicionamiento político era la lucha contra el modelo, reconociendo las especificidades de cada organización en la tarea común de oponerse y, consustancialmente, haciendo eje en la necesidad de crear una alternativa. Este punto es de desatacar pues, en aquel momento político, la alternativa no significaba una vocación de toma del poder, entendiendo éste bajo la articulación del sistema de partidos. Las impugnaciones al "modelo" eran el modo de sintetizar su oposición al neoliberalismo, con un Estado ausente, basado en las impunidades del pasado y del presente. Al mismo tiempo, la MTCHC ha sufrido los avatares de la historia propia del país. Desde la crisis cuasi terminal del 2001 hasta el proceso posterior de recomposición del sistema político, pasando por la reorientación de las políticas nacionales desde el año 2003 y el inicio de las políticas de revisión de la causa memoria,

\footnotetext{
${ }^{42}$ En algunas memorias militantes, la Mesa sería producto justamente de intentar evitar un copamiento de estas organizaciones partidarias sobre las conmemoraciones de los 24 de marzo y de las disputas por imponer diferentes agendas en esas fechas que han operado siempre como ventanas de oportunidad para posicionarse y llamar la tensión en determinadas situaciones. Sería, pues, una iniciativa más marcada por las politicidades que tienen a H.I.J.O.S. y su red de afinidades políticas en el centro de la apuesta organizativa, a diferencia de otras versiones de coordinadoras o multisectoriales que fueron más efímeras.
} 
verdad y justicia. Todos estos acontecimientos y procesos impactaron en sus discusiones internas y en sus posicionamientos públicos, generando permanencias, nuevas adhesiones y algunos alejamientos. Un tópico central de estas discusiones y revisiones tuvo que ver con la discusión sobre el Estado, pero ello excede al momento de conformación y consolidación que hemos convertido en el objetivo de este artículo, aunque ya comenzaba a insinuarse en su agenda de discusión en los primeros años del nuevo ciclo. De todos modos, hacia fines del siglo pasado y en la inmediata antesala de diciembre del 2001, el componente de crítica al sistema de representación y las alternativas instituyentes de nuevos contornos de la política estaban presentes en diferentes espacios de militancia, como en la propia Mesa.

Fuera de esos diferentes tempos de las definiciones más generales sobre el orden deseable y la función condensadora que tenía la crítica al modelo neoliberal, es importante considerar otros rasgos de continuidad con culturas políticas anteriores. Una recurrencia en los modos de construir autorelatos es la apelación a las organizaciones del campo popular como colectivo de identificación. En este sentido, la mención recupera un nosotros muy presente en la genealogía de las izquierdas y nacional populares, siendo en la construcción práctica donde tales contornos de inclusión son definidos y no apriorísticamente. De este modo, el campo popular estaría compuesto, para la Mesa, por las organizaciones que desde su cotidianeidad luchaban "contra el modelo."

\section{Las otras Mesas}

Un dato singular, referido al proceso político de articulación del que da cuenta la trayectoria de la MTDHC, es que su formato organizativo y sus definiciones han prohijado otros espacios alternativos y complementarios de acción que tematizaban y accionaban políticamente en conflictos y espacios organizativos singulares. En esta línea, tempranamente se constituyó en Córdoba la Mesa de Estudiantes Secundarios; arena de 
articulación de fuerzas estudiantiles secundarias, generalmente con representación de sus centros de estudiantes, que movilizaron y actuaron inscribiendo problemáticas exclusivas de este sector educativo. En particular, se destaca su militancia en pos de sedimentar en el calendario rememorativo y de protesta episodios represivos que tuvieron a la enseñanza media y sus estudiantes como objeto de la represión pre y posdictatorial. En torno a la memoria de La Noche de los Lápices, el colectivo secundario actualizó otros eventos represivos desarrollados en Córdoba, configurando anclajes locales para una memoria del pasado reciente que articulara significativamente ambos eventos. Un caso ejemplar de represión a estudiantes secundarios ha sido, en Córdoba, el de Escuela de Comercio Manuel Belgrano, episodio ya referido en este trabajo al abordar los orígenes de la MTDHC. Simultáneamente, inscribían reclamos tendientes a actualizar la situación de los estudiantes secundarios en Córdoba. En un volante de convocatoria a la actividad del 16 de septiembre, afirmaban:

\footnotetext{
Reclamamos la educación Pública y Gratuita, en contra del ajuste a la educación.

Peleamos oponiéndonos al terrorismo de estado y la represión a los jóvenes. Luchamos por el juicio y castigo a los genocidas.

Reivindicamos la memoria para combatir las injusticias del presente, apostando a definir entre todos un futuro mejor (Red de bondis. Mesa de trabajo de estudiantes secundarios. Córdoba, septiembre de 2001).
}

Como la mesa de los secundarios surgió para tematizar y politizar un determinado sector y conflicto, a medida que la Mesa se consolidaba como espacio de encuentro entre organizaciones fue necesario construir una nueva herramienta organizativa para redimensionar la acción de los escraches.

En efecto, por último haremos referencia a la constitución de la Mesa de Escrache Popular (en adelante MEP) que, motorizada por la agrupación H.I.J.O.S. Regional Córdoba, vino a potenciar a los escraches como herramienta de lucha política contra la impunidad. En particular, en el escenario local, los escraches fueron desde 1998 el repertorio de protesta más dinámico y novedoso del mapa del activismo mediterráneo. Originalmente promovidos por las organizaciones locales del $\mathrm{MDH}$, y centralmente por 
H.I.J.O.S., los escraches a genocidas impunes por los crímenes de lesa humanidad, y a las instituciones que actuaron como vehiculizadoras de la acción represiva del Estado Terrorista, lograron convertirse en asunto común de la MTDHC. Sin embargo, y aunque el núcleo de las demandas referidas a la no resolución de las demandas históricas del MDH tenía amplio consenso en la Mesa, al inicio del nuevo siglo la creación de la MEP, inicialmente surgida de la invitación que H.I.J.O.S. realizó a organizaciones con las que tenía marcada afinidad, posibilitó afianzar las relaciones con quienes existía una fuerte coincidencia tanto en las posiciones políticas más generales como en los modos de construir prácticas políticas novedosas.

En la carta inicial de invitación, la Comisión de Escrache de esta agrupación señalaba la necesidad de "conformar una herramienta que intensifique en Córdoba la condena social". La lectura política de un contexto signado por la imposibilidad de la justicia y la verdad, a partir de la vigencia de las Leyes de Impunidad-p.e. ley de Punto Final y de Obediencia Debida y los indultos presidenciales a los represores procesados y condenados en 1989 y 1990 respectivamente ${ }^{43}$ - produjo el marco de legitimación de esta apertura organizativa.

\section{La continuidad del escrache como herramienta de lucha}

Dentro del repertorio de confrontación de fines de los noventa e inicios de los dos mil, el formato de protesta que se convirtió en paradigmático de la MTDHC es el escrache, en coincidencia con la renovación en las formas de lucha que la agrupación H.I.J.O.S. aportó al MDH. En él se anuda una acción política contemporánea -como

\footnotetext{
${ }^{43}$ Las leyes mencionadas y los indultos configuraron un nuevo escenario de desprocesamiento institucional y judicial de la cuestión de los derechos humanos en Argentina. Ellas limitaron severamente la continuidad de los juicios y desandaron las efectivas condenas que hasta entonces se habían realizado. Por ello, son conocidas como leyes de impunidad ya que hasta que se revirtieron sus efectos, declarando su nulidad e inconstitucionalidad, siguieron frenando los procesos de justicia. De tal suerte que en Argentina la denominada justicia transicional tuvo efectos más que limitados e incluso reversiones.
} 
plantea Nardacchione- que inscribe un nosotros, instala una demanda y una pretensión de generalización que incluye la indeterminación del sentido público por la presencia de un tercero juzgante (NARDACCHIONE, 2005). Pero además, es desde su propio proceso de gestación y puesta en acto un ejemplo de performance política, no sólo por los sentidos a él asociados sino por la distinción entre los diferentes momentos de su efectivización: la preparación, la salida a la comunidad de vecinos y finalmente el escrache, como el momento culmine de su aparición en escena y esa manifestación protestataria que se haría característica de una politicidad renovada.

Una de las actividades centrales que moduló la agenda de la Mesa fueron los escraches a los ex centros clandestinos de la represión, además de los realizados en los domicilios de los represores que resultan más conocidos. En relación a los primeros, éstos se constituyeron en el antecedente mediato de la entrega a los organismos que, a partir de las leyes respectivas que avalaron el gobierno nacional y provincial a realizarlos. En las memorias locales, fueron muy simbólicas y siguen actualmente siendo reconocidas como acciones de envergadura las caravanas dirigidas hasta el ex centro clandestino de La Perla, hoy convertido en Espacio de Memoria, y que se halla ubicado camino a la turística ciudad de Carlos $\mathrm{Paz}^{44}$. Estas caravanas fueron un modo pelicular de señalar un espacio, de inscribir públicamente una injusticia. Las caravanas fueron asimismo la resignificación de una acción, que es a la vez manifestación y escrache, y formó parte del repertorio de protesta de la MTDHC. Las enormes caravanas, que desde el centro capitalino partían en ocasión de los 10 de diciembre, se convirtieron así en un clásico ejercicio de protesta y de señalización de la memoria.

\footnotetext{
${ }^{44}$ La Perla es considerado el mayor centro clandestino del interior del país; fue operativo y epicentro de la represión clandestina entre el golpe de Estado de marzo de 1976 y fines de 1978. De aquellos años procede igualmente la mayor cantidad de desaparecidos.
} 
Con relación a los escraches a represores ${ }^{45}$, se contorneó un formato modular que incluyó lo que podemos reseñar como una secuencia, a partir de los materiales consultados: anticipación a la prensa, difusión en el barrio, congregación de agrupaciones afines, reparto de material político pre-escrache con mapas, biografía represora y foto y, ya en el día convenido, marcha y acto frente al domicilio, entrega de materiales a las y los vecinos y señalización de la casa. Si bien la convocatoria fue oscilante en el número de participantes y hasta en las agrupaciones presentes, no es menor que en varias ocasiones los manifestantes no pudieron llegar hasta los domicilios por encontrarse previamente vallado y custodiado por personal de la policía.

Se trataba entonces de nuevos modos de la politicidad juvenil, nuevas experiencias de construcción de comunidad política, en las que se estilizaban y maleaban los límites de lo señalable y exigible: no sólo marcar la carencia del juicio que no llega, sino invitar a ejercitar una condena social, reinventando las antiguas charivaris (que en los albores de la modernidad señalaban en rituales públicos a los responsables de un daño individual o colectivo) y ampliando los sentidos de aquel pasado en el presente. En Córdoba en particular, hay notas locales que ayudan a pensar en los trabajos políticos específicos que el MDH realizaba en diferentes lugares del país. De todos los escraches realizados por la MTDHC y, desde su constitución por la MEP, destacamos uno que finalmente no fue realizado por las repercusiones políticas generadas, llegando a involucrar directamente a un ministro del gobernador. Fue la coyuntura creada en torno a un inminente escrache al arzobispo Raúl Primatesta -pergeñado en ocasión de su retiro de la máxima jerarquía eclesiástica de la comunidad católica- que se operó una ventana política para leer nuevos rasgos de politicidad juvenil y también para observar los rechazos que ese modo de inquirir el pasado que no pasa producía en sectores claves de la sociedad cordobesa.

\footnotetext{
${ }^{45}$ Expresión popular para referir a los responsables y ejecutores de la represión. En su mayoría pertenecían a fuerzas armadas o de seguridad, pero también podía señalarse a civiles comprometidos con el ejercicio represivo; incluso se escrachó a apoyos civiles corporativos, como la Fundación Mediterránea.
} 
El cardenal había dirigido la comunidad católica local desde 1966. En 1999, con una edad avanzada, se decidió su alejamiento. Fue antes de su despedida, cuando los organismos de derechos humanos locales comenzaron a publicitar un escrache, dada las complicidades que los allegados a las y los represaliados le atribuían con la última dictadura cívico militar en Córdoba. El abanico de señalamientos incluía desde no haberlos recibido cuando fueron en busca de auxilio por sus familiares hasta la centralidad que su actuación política tuvo junto al ex general Luciano B. Menéndez en definir el escenario previo al golpe. Este ex general fue comandante del III Cuerpo de Ejército con asiento en Córdoba en los años de mayor intensidad represiva entre 1975 y 1979. Lo novedoso es que frente a cierta habitualidad de los escraches en el espacio público local, la noticiabilidad de un posible escrache al máximo referente de la estructura jerárquica de la iglesia generó un renovado macartismo que tuvo en la figura de un funcionario de la gobernación provincial, el ministro Oscar Aguad, a su referente más preciso, alertando sobre "posibles disturbios":

\begin{abstract}
Los servicios de inteligencia del Estado nacional y provincial advirtieron a la Iglesia de Córdoba que grupos vinculados a organizaciones políticas de izquierda preparan un "escrache" y tiene previsto provocar disturbios en la despedida que el viernes a la tarde se realizará en la Catedral al cardenal Raúl Francisco Primatesta (...) son los mismos que denunció días atrás el ministro de asuntos institucionales Oscar Aguad, quien habló de un plan para desestabilizar al gobierno (...) Se trata de la agrupación Quebracho, Patria Libre, Partido de la Liberación (...) agrupación HIJOS (...) En la denuncia de Aguad se identificó a los activistas que están actuando en cuanta manifestación pública con disturbios se produjo en Córdoba desde 1995. - (La Mañana de Córdoba, 4 marzo 1999, p. 1 y 2)
\end{abstract}

La extensa cita se justifica por la recurrencia en los argumentos y en los modos de tematizar la disidencia. El uso peyorativo del concepto "activistas" es un dato regular en la cultura política de los dirigentes en el gobierno, independientemente de su signo partidario y de la distancia entre contextos y conflictos para los que se usó tal referencia. La asociación entre activistas de izquierda, incidentes y desestabilización del gobierno seguía siendo un fantasma relativamente fácil de azuzar aún entonces, dada la insistente 
sedimentación de un discurso estigmatizador de las violencias en general y de ciertas militancias en particular que se había acendrado en el imaginario posdictatorial. Otras violencias (del estado, del mercado) tenían menos prensa y eran más naturalizadas que aquella que convertía a la disidencia y a su potencial disruptivo en amenaza del orden. Pero además, no hay acabada referencia al MDH, ni a la MTDHC o la MEP; solamente se incluyó a H.I.J.O.S. en una operación discursiva que buscaba deslegitimarlos al ponerlos en pie de igualdad de actuación con partidos o agrupaciones de izquierda, algunas de las cuales habían apoyado el uso de acciones directas en las formas de protesta contra el modelo. Tampoco menciona que entre esa diversidad de nucleamientos había ya diferencias notables, y si bien en ocasiones habían participado juntos de acciones de escraches, también había toda una discusión interna sobre los sentidos y formas de los mismos que, como se explicó, estuvieron en la base de la conformación de la MTDHC y la MEP. Por último, especificar que se trataba de redes de activistas que venían actuando desde 1995 hacía referencia al contexto de crisis que motivó la renuncia anticipada del gobernador Angeloz, como si la responsabilidad de este acontecimiento estuviese en la protesta de los afectados y no en la crisis financiera y política generada por las propias políticas públicas del ex gobernador radical.

En definitiva, este escrache que no fue en 1999, año en que la cuestión Pinochet había reinstalado las violaciones sistemáticas a los derechos humanos y la impunidad vigente en los países del Cono Sur, puso en escena por la intervención del ministro la supuesta amenaza del uso de la violencia política como la peor de las violencias, aunque la posibilidad de desestabilización del sistema de derecho de un escrache a Primatesta fuese realmente dudable. Claro es también que se basaba en algunos hechos ciertos, como la activa presencia de variadas corrientes de izquierda en la escena política local, cuyas juventudes tuvieron protagonismo o al menos presencia en diferentes conflictos, incluso en los disturbios en los que se produjo la quema de la Casa Radical en junio de $1995^{46}$,

\footnotetext{
${ }^{46}$ Un episodio de contienda política que fue caracterizado por sucesivas protestas contra la situación financiera provincial que había suspendido el cobro de los salarios a los trabajadores provinciales. Tuvo su
} 
como lo es también que, hasta ahora, no se ha estudiado en profundidad el grado de participación en aquellas violencias de otros actores mucho más significativos numéricamente como las corrientes sindicales, varias de ellas enroladas en el peronismo, y de grupos inorgánicos que se sumaron espontáneamente a la misma. Lo interesante es el ejercicio preventivo realizado por el ministro, en un acto de igualación entre organismos y partidos de izquierda que tenían más que frágiles puntos de coincidencia en las modalidades y ocasiones de la protesta. Pero además, denota la centralidad que la comunidad católica tenía en la sociedad cordobesa y sus más que aceitados contactos con la clase política. Ningún otro escrache a militares, médicos o civiles represores generó una intervención política preventiva de tal magnitud. Podría pensarse que si los militares golpistas ya no gozaban de sus viejas solidaridades, la iglesia seguía teniendo poder para vetar el debate público sobre su propia responsabilidad en los años de mayor intensidad represiva en la provincia. En definitiva, con los materiales del pasado reciente, las interpretaciones preventivas de un posible escrache mostraban la plasticidad del uso del pasado para disputar los límites de aquello que debía ser públicamente discutido sobre las responsabilidades y las actitudes sociales en la dictadura.

\section{Conclusiones}

Al iniciar este artículo nos preguntábamos por la conformación y consolidación de la MTDHC como una instancia interorganizacional novedosa que permitió articular diferentes luchas y ampliar los sentidos asociados al marco de los derechos humanos. En particular, buscamos reflexionar sobre ese proceso desde algunas claves que repusieran las complejidades de pensar la acción política y las luchas por derechos humanos en un régimen de historicidad diferente y en su articulación con las derivas del tratamiento

momento de mayor despliegue de violencia colectiva cuando una manifestación culminó con el ataque a la sede partidaria provincial de la Unión Cívica Radical, el partido político del gobernador Eduardo César Angeloz. El hecho incluyó la destrucción parcial e incendio de parte de las instalaciones de la planta baja, así como la rotura de elementos simbólicos como el busto de un viejo líder partidario que fue sacado a la calle y atacado por los manifestantes. 
político e institucional de las demandas que la Mesa expresaba. Ello nos llevaba a indagar los modos y sentidos con que las temporalidades habitan y actúan en la acción militante (y en sus efectos) y cómo se entrelazan con la creación de procesos de legitimación política y de actuación pública contestataria.

En este marco de indagación propuesto, hay una primera cuestión que el artículo expone y es el laborioso trabajo de trasmisión y traducción que está en la base de la creación política, una (re)mixtura de viejos y nuevos tópicos y experiencias que se relocalizan en la acción política y tejen urdimbres de temporalidades varias desde el presente de las y los protagonistas de la Mesa. En efecto, la MTDHC es una experiencia paradigmática en la que sedimentaron, por un lado, aquellas transformaciones en términos de culturas políticas que la propia constitución de los derechos humanos como cuestión del debate prohijó y, por otro, nuevos rasgos de politicidad juvenil acendrados en las luchas y experiencias de los años noventa que tuvieron en la oposición al modelo su punto de confluencia. Es, asimismo, una experiencia que logró configurar un espacio de encuentro entre organizaciones que, desde sus espacios singulares, aportaron a la resignificación del marco de los derechos humanos como legitimación de las luchas contemporáneas. Un espacio de confluencia y de encuentro que no ha estado exento de tensiones, sobre las que se vuelve preciso un mayor análisis, pero también de producción de consensos que, ante la apertura de nuevas coyunturas políticas, requiere trabajar con mayor atención el impacto que estas produjeron en aquellos acuerdos.

De allí que esta exploración nos devuelve algunas certezas. En primer lugar, la novedad del espacio de la Mesa como espacio de coordinación permanente y su influencia decisiva en la instalación de las conmemoraciones alusivas a los efectos del terror de Estado en Córdoba. Su importancia como estructura movilizadora es crucial para situar, además, la configuración de un repertorio modular de protesta (y recordación), donde las marchas del 24 de marzo y los escraches se han convertido en notas de identidad del MDH. Igualmente, la conformación de un cierto repertorio no elude su potencial disruptivo o amenazante. Por el contrario, el carácter disruptivo de estos formatos de 
protesta es históricamente construido, como lo pone de manifiesto el caso del frustrado escrache al referente máximo de la grey católica en Córdoba. Por otra parte, no solo en el tiempo de la protesta hay novedades. Introducirnos en los modos en que se politizan las prácticas de estos jóvenes, destacando el lugar de la horizontalidad, el taller como instancia de participación y construcción colectiva y la definición conjunta de temas y agendas ha sido igualmente relevante. Politicidad juvenil y nuevas rasgos de militancia que no significan en la experiencia de la MTDHC un alejamiento de otras generaciones de militantes, sino una integración que recupera modalidades previas y las resignifica.

Repertorios de confrontación, de organización y discursivos que recrean diferentes temporalidades actuando en la acción política, volviendo aún más preciso seguir indagando sobre procesos de trasmisión y traducción entre generaciones y sobre la construcción histórica del compromiso político.

\section{Referencias Bibliográficas}

\section{Fuentes consultadas}

\section{Inéditas}

Base de datos de acción Colectiva en Córdoba (1984-2002). Base normalizada producida por Gordillo, Mónica (et. al) para los proyectos bajo su dirección de SECYT alojados en el área Historia del CIFFyH, UNC.

\section{Hemerográficas}

La Mañana de Córdoba, diario, Córdoba

La Voz del Interior, diario, Córdoba, Argentina.

La Hendija. Córdoba, Año 1, n. 3, 1998.

\section{Colecciones personales}

Volantes, afiches, cartas, documentos de trabajo y cartillas de la MTDHC.

\section{Recursos en línea}

Páginas institucionales de la MTDHC. Dos versiones referenciadas. 
1- MTDHC, 2006. Disponible en

http://www.derechoshumanoscba.org.ar/spip.php?article2079 [Consulta: junio de 2009]. 2- MTDHC, 2020. Nueva página institucional creada en el año 2019. Disponible en: https://mesadetrabajoporlosddhhdecordoba.com.ar/contenido/82/mesa-de-trabajo-porlos-derechos-humanos-de-cordoba-quienes-somos [Consulta: 9/6/2020].

\section{Bibliografía}

ALONSO, Luciano. La "Historia reciente" argentina como forma de Historia actual: emergencia, logros, ¿bloqueos? Historiografías, Zaragoza, n. 15, p. 72-92, 2018.

ALONSO, Luciano. Problemas de conceptuación en torno a las luchas por derechos humanos. In: BADANO, M. del R. (Comp.). Educación superior y derechos humanos". Reflexiones, apuestas y desafios. Entre Ríos: RIDDHH, Editorial UADER, 2019, p. 229250.

CONADEP. Informe Delegación Córdoba. Córdoba: Editado por Familiares de Detenidos y Desaparecidos por Razones Políticas, 1999.

FORTS Reiner. El derecho básico a la justificación: hacia una concepción constructivista de los derechos humanos. Estudios Políticos, Colombia, n. 26, p. 1-33, 2005. Disponible en

http://bibliotecavirtual.clacso.org.ar/ar/libros/colombia/iep/26/2\%20Reiner.pdf [Consultado en 7/5/2011].

HARTOG, François. Sobre la noción de régimen de historicidad. Entrevista con François Hartog. In: Delacroix, C.; Dosse, F.; García, P. Historicidades. Buenos Aires: Waldhuter, 2010, p. 145-163.

MARIANI, Ana. La vida por delante. Córdoba: Ediciones del Boulevard, 2006.

NARDACCHIONE, Gabriel. Acción y sentido: antagonismo y espacio público. In: SCHUSTER, F.; et al. (Comp.). Tomar la palabra. Estudios sobre protesta social y acción colectiva en la Argentina contemporánea. Buenos Aires: Prometeo, 2005, p. 85109.

OBERTI, Alejandra y PITTALUGA, Roberto. Memorias en montaje. Escrituras de la militancia y pensamientos sobre la historia. Buenos Aires: El cielo por asalto, 2006.

OVIEDO, Silvina y SOLIS, Ana Carol. Violencia institucionalizada y formas de resistencia social: los organismos de Derechos Humanos en Córdoba durante la dictadura. 
Trabajo Final para acceder a la Licenciatura en Historia, Córdoba: Universidad nacional de Córdoba, Inédito, 2006.

PUTTINI, María Paula. Hijos e hijas por la Identidad y la Justicia contra el Olvido y el Silencio, Regional Córdoba. Resignificación de las demandas de memoria, verdad y justicia durante la segunda mitad de la década del 90’. Trabajo final de Licenciatura en Historia. Escuela de Historia, Facultad de Filosofía y Humanidades. Inédito, 2020. Directora: Solis, Ana Carol.

RAGGIO, Sandra. Memoria de la Noche de los lápices. Tensiones, variaciones y conflictos en los modos de narrar el pasado reciente. Entre los libros de la buena memoria. La Plata: FaHCE, UNLP, 2017.

SCOTT, James. Los dominados y el arte de la resistencia. Discursos ocultos. México: Ediciones Era, 2000.

SERVETTO, Alicia. De la Córdoba combativa a la Córdoba militarizada 1973-1976. Córdoba: Ferreyra Editor, 1998.

SERVETTO, Alicia. Córdoba en los prolegómenos de la dictadura. La política del miedo en el gobierno de Lacabanne. Estudios, Revista del Centro de Estudios Avanzados, Córdoba, n. 15, p. 143-156, 2004.

SOLIS, Ana Carol. Las acciones pro - derechos y justicia: construyendo el marco de la impunidad (1994-1996). Anuario n ${ }^{\circ} 21,2005-2006$. "Movimientos sociales. Experiencias históricas. Tendencias y conflictos." Rosario: Escuela de Historia de la Facultad de Humanidades y Artes de la Universidad Nacional de Rosario, p. 221-253, 2006.

SOLIS Ana Carol. Organizar la solidaridad contra la represión en Córdoba. Revisiones desde la historia reciente y las políticas de memoria. Anuario Virtual de la Escuela de Historia, Córdoba, Escuela de Historia, año 10, n. 16, p. 71-92, 2019.

SOLIS, Ana Carol. ¿La plaza vacía? Viejos y nuevos tópicos en la lucha por derechos humanos" Ponencia: Primeras Jornadas Nacionales de Historia de Córdoba, CIFFYH. Córdoba: Facultad de Filosofía y Humanidades, UNC, Inédita, 2009.

SOLIS, Ana Carol. Los Derechos Humanos en la Cultura Política desde la Acción Colectiva de una Democracia Excluyente. Córdoba entre 1989 y 2002. Tesis de Maestría en Partidos Políticos. Córdoba: Centro de Estudios Avanzados, UNC. Inédita, 2011. 
SOLIS, Ana Carol. La cuestión de los derechos humanos: de la posdictadura a la democracia excluyente. (Córdoba, 1989-2002). In: GORDILLO, M.; ARRIAGA, A. E.; FRANCO, M. J.; MEDINA, L., NATALUCCI, A.; SOLIS, A. C. La protesta frente a las reformas neoliberales en la Córdoba de fin de siglo. Córdoba: Ferreyra Editor, 2012, p. 307-352.

SOLIS, Ana Carol. De las comisiones a los organismos en Córdoba: derechos humanos, dictadura y democratización. In: KOTLER, R. (Coord.). En el país del sí me acuerdo. Los orígenes nacionales y transnacionales del movimiento de derechos humanos en Argentina: de la dictadura a la transición. Buenos Aires: Imago Mundi y Red Latinoamericana de Historia Oral, p. 129-156, 2014.

SVAMPA, Maristella La sociedad excluyente. Argentina bajo el signo del neoliberalismo, Buenos Aires: Taurus, 2005. 